\title{
Current strategies to minimize the bleeding risk of warfarin
}

This article was published in the following Dove Press journal: Journal of Blood Medicine

31 July 2013

Number of times this article has been viewed

\author{
David Snipelisky' \\ Fred Kusumoto ${ }^{2}$ \\ 'Department of Medicine, Mayo Clinic, \\ Jacksonville, FL, USA; ${ }^{2}$ Division of \\ Cardiovascular Diseases, Mayo Clinic, \\ Jacksonville, FL, USA
}

\begin{abstract}
For many decades, the vitamin $\mathrm{K}$ antagonist warfarin has been the mainstay of treatment for various conditions that require anticoagulation, including atrial fibrillation. Although the efficacy of warfarin in both prevention and treatment of thrombosis has been demonstrated in numerous randomized clinical studies, one of the major concerns that remains is the risk of bleeding. Although the net benefit of warfarin has been demonstrated in large clinical trials, physicians and patients alike are often reluctant to use warfarin because of the bleeding risk. Bleeding in patients on warfarin is generally minor requiring no intervention, but the development of a major bleeding complication is associated with significant morbidity and can even be fatal. Numerous risk factors that increase the probability of having a hemorrhage while on warfarin have been identified, and bleeding risk scores have been developed. Various strategies to reduce bleeding risks have been developed and have become more important, since the use of warfarin and other anticoagulants continues to increase. This paper provides a concise review of bleeding risk factors, while outlining recommendations both physician and patients can incorporate to help reduce the risk of bleeding.
\end{abstract}

Keywords: hemorrhage, warfarin, thrombosis, anticoagulants, dabigatran, vitamin $\mathrm{K}$ antagonist

\section{Introduction}

Warfarin, the most commonly used anticoagulant in North America, is a vitamin K antagonist that is demonstrated to be efficacious in the prevention of thrombosis and thromboembolism. Its use dates back to the $1950 \mathrm{~s}$, when it was approved as an anticoagulant in the United States. ${ }^{1}$ Current indications for its use include the prevention of thrombosis in patients either at risk for or with a history of thrombotic events. Such patients include those with thrombophilias, prosthetic heart valves, presence of deep venous thrombosis or pulmonary embolism, and in patients with atrial fibrillation at risk for thromboembolism. ${ }^{1,2} \mathrm{~A}$ large subset of patients taking this medication are those with atrial fibrillation and current projections show that in 2020 more than 7.5 million people in the United States will be diagnosed with atrial fibrillation. Therefore, the utilization of warfarin will expand within the near future. ${ }^{3}$

Although warfarin conveys a clear net benefit and its anticoagulant effects can be easily measured by the international normalized ratio (INR), inherent to its use is the risk of life-threatening hemorrhage. This is a common concern for physicians and patients alike upon prescribing this medication. Since its introduction as an approved anticoagulant, many studies have evaluated its bleeding risk. ${ }^{1-10}$ This review will summarize
Correspondence: David Snipelisky Department of Medicine, Mayo Clinic, 4500 San Pablo Road, Jacksonville, FL 32224, USA

Tel +l 9049532000

Email snipelisky.david@mayo.edu 
the risk of bleeding with warfarin and discuss methods for estimating and mitigating risk of bleeding in an individual patient (Table 1).

\section{Bleeding incidence}

Numerous studies have shown that the incidence of major bleeding in patients on warfarin ranges from $0.4 \%-7.2 \%$ per year. ${ }^{1,4}$ Minor bleeding rates can be as high as $15.4 \%$ per year. ${ }^{4}$ This wide range is thought to be a result of the numerous patient-specific factors that can alter metabolism. ${ }^{1}$ In addition, earlier studies often had different definitions for major bleeding events. ${ }^{4}$ More recent studies have been more consistent and usually define major bleeding as fatal

Table I Selected risk factors that increase bleeding risk with recommendations

\begin{tabular}{|c|c|}
\hline Risk factor & Recommendations \\
\hline $\begin{array}{l}\text { First } 90 \text { days } \\
\text { of treatment }\end{array}$ & - Increase frequency of INR monitoring \\
\hline Intensity & - Not recommended to reduce INR goal \\
\hline of anticoagulation & $\begin{array}{l}\text { - Discontinue concurrent aspirin therapy } \\
\text { in patients with stable coronary artery } \\
\text { disease }\end{array}$ \\
\hline Older age & $\begin{array}{l}\text { - Decrease starting dose of warfarin } \\
\text { - Increase frequency of INR monitoring }\end{array}$ \\
\hline $\begin{array}{l}\text { Comorbidities (renal } \\
\text { and hepatic dysfunction, } \\
\text { diabetes mellitus, } \\
\text { hypertension) }\end{array}$ & $\begin{array}{l}\text { - Control comorbid conditions with medical } \\
\text { therapies }\end{array}$ \\
\hline Hospitalized patients & $\begin{array}{l}\text { - Increase frequency of INR monitoring both } \\
\text { during hospitalization and in short-term } \\
\text { period after discharge }\end{array}$ \\
\hline $\begin{array}{l}\text { Lack of knowledge and } \\
\text { compliance }\end{array}$ & $\begin{array}{l}\text { - Continually educate patient about diagnosis } \\
\text { and rationale for warfarin therapy } \\
\text { - Maintain a team approach } \\
\text { - Recommend patients to obtain a primary } \\
\text { care physician and involve primary care } \\
\text { physician in care }\end{array}$ \\
\hline $\begin{array}{l}\text { INR monitoring } \\
\text { variability between } \\
\text { different medical centers }\end{array}$ & $\begin{array}{l}\text { Ensure appropriate frequency of INR } \\
\text { monitoring }\end{array}$ \\
\hline $\begin{array}{l}\text { Diet and medication } \\
\text { changes }\end{array}$ & $\begin{array}{l}\text { - Advise patients to keep consistent diet } \\
\text { - Recognize medications that can alter } \\
\text { warfarin metabolism and increase } \\
\text { frequency of INR monitoring during this } \\
\text { period }\end{array}$ \\
\hline Genetic variations & $\begin{array}{l}\text { Not recommended to test for such } \\
\text { variations }\end{array}$ \\
\hline $\begin{array}{l}\text { Periprocedural and } \\
\text { operative settings }\end{array}$ & $\begin{array}{l}\text { - Ensure discontinuation of warfarin } 5 \text { days } \\
\text { prior to procedure with bridging therapy, } \\
\text { if needed } \\
\text { - Educate patient regarding rationale for } \\
\text { transient discontinuation of warfarin } \\
\text { therapy }\end{array}$ \\
\hline
\end{tabular}

Abbreviation: INR, international normalized ratio. hemorrhage, bleeding requiring hospitalization, bleeding requiring two or more transfusions of packed red blood cells, and bleeding at critical sites, including intracranial and retroperitoneal. Patients with major bleeds have a several-fold increase in death for up to one year following the incident. ${ }^{2}$

Many of the current studies evaluating the incidence of bleeding in patients on warfarin have evaluated large cohorts of patients with atrial fibrillation (Table 2)..$^{4-10}$ The Atrial Fibrillation Follow-up Investigation of Rhythm Management (AFFIRM) trial studied more than 4,000 patients in evaluation of rate versus rhythm approaches in controlling atrial fibrillation, yet found that the annual risk of major bleeding was approximately $2 \%$ per year, with minor bleeding incidents occurring in more than $18 \%$ of enrolled patients. The study reported that the majority of patients were supratherapeutic at time of hemorrhage. ${ }^{4}$ In the Rivaroxaban Once Daily Oral Direct Factor Xa Inhibition Compared with Vitamin K Antagonism for Prevention of Stroke and Embolism Trial in Atrial Fibrillation (ROCKET AF) trial, patients were randomized to warfarin or the factor Xa inhibitor rivaroxaban. In patients randomized to warfarin, more than $14 \%$ had at least one incident of a bleeding event. ${ }^{5}$ The Anticoagulation and Risk Factors in Atrial Fibrillation (ATRIA) cohort of more than 11,000 patients also showed that those on warfarin therapy have a higher rate of bleeding, especially that of intracranial bleeds in which 59 patients suffered an intracranial hemorrhage in the warfarin cohort, compared to 29 without anticoagulation. Intracranial sites are of extreme concern as treatment options can be very limited. ${ }^{6}$

Smaller studies have evaluated bleeding risk in other patient populations. ${ }^{7-13}$ In a group of 820 patients on warfarin, of which $47 \%$ had a diagnosis of venous thromboembolism, investigators found that major bleeding events occurred at a rate of $6.5 \%$ per year, with 87 patients having a major bleeding event. ${ }^{7}$ Similarly, Wells et al found that in a cohort of 222 patients with either pulmonary embolism or venous thromboembolism, $4.5 \%$ had a major bleed within an 18.5 month mean follow-up period. ${ }^{8}$ Kuijer et al, in a cohort of 241 patients, found that almost $4 \%$ of patients had a major bleeding event within the first 3 months of starting therapy for venous thromboembolism. ${ }^{9}$

\section{Bleeding risk factors}

An important risk factor of bleeding during warfarin therapy that is often neglected is the time period in which patients first initiate therapy. The first 90 days are the most variable in regard to the level of anticoagulation as the INR 
Table 2 Selected trials of major hemorrhage in patients on warfarin therapy

\begin{tabular}{|c|c|c|c|}
\hline Study/trial & Population & Outcome & Authors' conclusion \\
\hline AFFIRM $^{4}$ & $\begin{array}{l}\text { 4,060 patients in a trial comparing rate } \\
\text { versus rhythm approach in management } \\
\text { of atrial fibrillation; average follow-up of } \\
3.5 \text { years }\end{array}$ & $\begin{array}{l}\text { Major bleeding occurred in } 260 \text { patients } \\
(6.4 \%) \text { with annual incidence of approximately } \\
2 \% \text { per year; non-CNS sites occurred in } 203 \\
\text { of patients ( } 7.3 \%) \text {, while CNS hemorrhages } \\
\text { occurred in } 59 \text { patients ( } 2.1 \%) \text {; minor bleeding } \\
\text { occurred in } 738 \text { patients }(18.2 \%)\end{array}$ & $\begin{array}{l}\text { Risk factors for bleeding need } \\
\text { to be identified and used to plan } \\
\text { therapy }\end{array}$ \\
\hline ROCKET-AF 5 & $\begin{array}{l}\text { I4,264 patients with nonvalvular atrial } \\
\text { fibrillation randomized to receive either } \\
\text { warfarin or rivaroxaban; } 7,133 \text { patients } \\
\text { on warfarin ( } 50.0 \%) \text {, with median study } \\
\text { follow-up period } 707 \text { days }\end{array}$ & $\begin{array}{l}\text { Minor and major bleeding occurred in } \\
\text { I,449 total patients ( } 14.5 \% \text { ) on warfarin; } \\
\text { rate of major bleeding, 3.4\%, intracranial } \\
\text { hemorrhage, } 0.7 \% \text {, and gastrointestinal } \\
\text { bleed, } 2.2 \%\end{array}$ & $\begin{array}{l}\text { Bleeding remains most } \\
\text { worrisome complication of } \\
\text { anticoagulation therapy }\end{array}$ \\
\hline ATRIA $^{6}$ & $\begin{array}{l}\text { Cohort of II } 526 \text { patients with nonvalvular } \\
\text { atrial fibrillation, of which } 6,320 \text { were } \\
\text { on warfarin compared to } 5,089 \text { without } \\
\text { anticoagulation; median follow-up period } \\
\text { of } 2.20 \text { years ( } 25 ; 34 \text { I person-years) }\end{array}$ & $\begin{array}{l}59 \text { versus } 29 \text { incidents of intracranial } \\
\text { hemorrhage and II } 8 \text { versus } 119 \text { incidents } \\
\text { of gastrointestinal bleeding in patients on } \\
\text { warfarin therapy compared to patients on } \\
\text { no therapy, respectively }\end{array}$ & $\begin{array}{l}\text { Warfarin associated with } \\
\text { an almost two-fold adjusted } \\
\text { increased risk of intracranial } \\
\text { hemorrhage compared with } \\
\text { no warfarin therapy and } \\
\text { no significant increase in } \\
\text { nonintracranial hemorrhage }\end{array}$ \\
\hline RE-LY'10 & $\begin{array}{l}\text { I8, II } 3 \text { patients with atrial fibrillation } \\
\text { randomly assigned to either warfarin } \\
(6,076 \text { patients) or dabigatran therapy; } \\
\text { mean follow-up period } 2.0 \text { years }\end{array}$ & $\begin{array}{l}\text { Rate of major bleeding } 3.4 \% \text { per year and } \\
\text { hemorrhagic stroke } 0.38 \% \text { in warfarin group }\end{array}$ & $\begin{array}{l}\text { Major hemorrhage remains } \\
\text { complication of warfarin therapy }\end{array}$ \\
\hline Multiple trials" & $\begin{array}{l}\text { Analysis of data from five randomized } \\
\text { controlled trials, including Atrial Fibrillation, } \\
\text { Aspirin, Anticoagulation Study; Boston Area } \\
\text { Anticoagulation Trial for Atrial Fibrillation } \\
\text { Study; Canadian Atrial Fibrillation } \\
\text { Anticoagulation Study; Stroke Prevention } \\
\text { in Atrial Fibrillation Study; and Veterans } \\
\text { Affairs Stroke Prevention in Nonrheumatic } \\
\text { Atrial Fibrillation Study; evaluated } \\
\text { I,889 patient-years receiving warfarin }\end{array}$ & $\begin{array}{l}\text { Annual rate of major hemorrhage } 1.3 \% \text { in } \\
\text { patients receiving warfarin compared to } \\
1.0 \% \text { in the control group and } 1.0 \% \text { in the } \\
\text { aspirin group }\end{array}$ & $\begin{array}{l}\text { Increased risk of bleeding in } \\
\text { patients on warfarin compared } \\
\text { to no therapy or aspirin therapy }\end{array}$ \\
\hline ACTIVE $W^{12}$ & $\begin{array}{l}\text { Patients randomized to receive either } \\
\text { aspirin-clopidogrel combination } \\
\text { ( } 3,335 \text { patients) or warfarin } \\
\text { ( } 3,37 \text { I patients); mean follow-up } \\
\text { I.3 years }\end{array}$ & $\begin{array}{l}\text { I0I patients ( } 2.42 \% \text { annual risk) versus } \\
93 \text { ( } 2.21 \% \text { annual risk) with major } \\
\text { hemorrhage and } 568 \text { patients ( } 13.58 \% \text { annual } \\
\text { risk) versus } 48 \text { I patients ( } 11.45 \% \text { annual risk) } \\
\text { in patients on warfarin compared to those on } \\
\text { aspirin-clopidogrel combination; intracranial } \\
\text { bleeds more common in patients on warfarin }\end{array}$ & $\begin{array}{l}\text { Bleeding risk increased in } \\
\text { patients receiving warfarin }\end{array}$ \\
\hline SPORT IF ${ }^{13}$ & $\begin{array}{l}3,922 \text { patients randomized to receive } \\
\text { either warfarin ( } 1,962 \text { patients) } \\
\text { or ximelagatran; mean follow-up } \\
20 \text { months }\end{array}$ & $\begin{array}{l}\text { Hemorrhagic stroke occurred in two patients } \\
\text { in warfarin subset ( } 0.06 \% \text { per year) and seven } \\
\text { patients developed subdural hematoma; } \\
\text { major extracerebral bleeding occurred in } \\
84 \text { patients on warfarin ( } 3.1 \% \text { per year) }\end{array}$ & $\begin{array}{l}\text { Bleeding risk, especially in } \\
\text { extracranial sites, remains } \\
\text { substantial in patients receiving } \\
\text { warfarin }\end{array}$ \\
\hline Kuijer et al ${ }^{9}$ & $\begin{array}{l}\text { Bleeding score constructed based on } \\
\text { cohort of } 24 \text { I patients; mean follow-up } \\
3 \text { months }\end{array}$ & $\begin{array}{l}\text { Major bleeding complications occurred in } \\
\text { nine patients ( } 3.7 \%), \text { of which seven } \\
\text { occurred in the high-risk group }\end{array}$ & $\begin{array}{l}\text { Bleeding complications are } \\
\text { important to consider in patients } \\
\text { undergoing warfarin therapy }\end{array}$ \\
\hline Wells et $\mathrm{al}^{8}$ & $\begin{array}{l}\text { Outpatient Bleeding Risk Index accuracy } \\
\text { verified in } 222 \text { patients with deep venous } \\
\text { thrombosis or pulmonary embolism; } \\
\text { mean follow-up } 18.5 \text { months }\end{array}$ & $\begin{array}{l}\text { Total of } 4.5 \% \text { of patients had episode of } \\
\text { major bleeding; risk of major hemorrhage } \\
\text { per } 100 \text { person-years } 0 \% \text { in low-risk group } \\
\text { and } 4.3 \% \text { in moderate-risk group }\end{array}$ & $\begin{array}{l}\text { Bleeding complications can } \\
\text { occur in patients on warfarin } \\
\text { and Outpatient Bleeding } \\
\text { Risk Index can be applied } \\
\text { to populations treated for } \\
\text { deep venous thrombosis and } \\
\text { pulmonary embolism }\end{array}$ \\
\hline
\end{tabular}

Abbreviations: CNS, central nervous system; AFFIRM, Atrial Fibrillation Follow-Up Investigation of Rhythm Management; ROCKET-AF, Rivaroxaban Once Daily Oral Direct Factor Xa Inhibition Compared with Vitamin K Antagonism for Prevention of Stroke and Embolism Trial in Atrial Fibrillation; ATRIA, Anticoagulation and Risk Factors in Atrial Fibrillation; RE-LY, Randomized Evaluation of Long-Term Anticoagulation Therapy; ACTIVE W, Atrial fibrillation Clopidogrel Trial with Irbesartan for prevention of Vascular Events; SPORT IF, Stroke Prevention using Oral Thrombin Inhibitor in atrial Fibrillation. 
can be labile, attributing to this risk. ${ }^{2,14,15}$ As well, the dose of warfarin therapy can have markedly different effects on individuals, making it a difficult medication to prescribe. ${ }^{14,15}$ Patients can have alternating medication doses, which is reflective of the difficulty in initiating therapy. ${ }^{2,3,14}$ Douketis et $\mathrm{al}^{16}$ found that major bleeding events occur more frequently within 3 months of starting therapy. In their study, 28 incidents of major bleeding events occurred within a 3-month period; 13 occurred within the first 7 days and 21 within the first 3 weeks. ${ }^{16} \mathrm{~A}$ similar result was seen by Landefeld et al. ${ }^{17}$ In their retrospective analysis of 565 records of patients with either atrial fibrillation, venous thrombosis, or prosthetic valves beginning therapy, within the first 30 days following initiation, patients were found to have a 10 -fold higher risk of bleeding than the remaining 11 months of the study. Three percent of patients had major bleeding events during this period, compared to $0.3 \%$ in the remaining 11 months. ${ }^{17} \mathrm{~A}$ meta-analysis of 29 randomized controlled trials and four prospective cohort studies showed that intracranial hemorrhage within the first 3 months of therapy is of concern. In this analysis, $1.48 \%$ of patients had an intracranial hemorrhage within the first 3 months, with 0.65 per 100 -patient years following. ${ }^{18}$ Conversely, a review of a registry of 5,477 patients found that the risk of ischemic stroke within the first 30 days of a diagnosis of atrial fibrillation is significantly higher than later on in the disease process. ${ }^{19}$ Another study of more than 125,000 found that the rate of hemorrhage was almost $12 \%$ within the first 30 days of treatment, compared to almost $4 \%$ overall. ${ }^{20}$ Although the bleeding risk remains elevated, physicians need to understand that the risk of adverse events from the thrombophilic condition exists. Therefore, it is important to first understand whether anticoagulation will be of benefit to each individual patient and, if so, more vigilant monitoring of the INR during the first 30 to 90 days of therapy is of utmost importance to avoid possible preventable bleeding events., ${ }^{2,314-20}$

Another risk factor that can increase one's risk of bleeding is the intensity of anticoagulation. Studies have shown that with higher intensities of anticoagulation measured by the INR, patients are at increased risk of hemorrhage. ${ }^{2,21-23} \mathrm{In}$ a study of 435 patients followed for more than 7 years that developed intracranial hemorrhage, the 3-month mortality in those patients on warfarin therapy was more than $50 \%$, compared to approximately $25 \%$ in patients not on warfarin. ${ }^{21}$ Japanese guidelines recommend a lower intensity of anticoagulation with an INR range of 1.6 to 2.6 in elderly patients because of the association between anticoagulation intensity and bleeding risk. ${ }^{22} \mathrm{~A}$ case control study at an academic medical center of 170 patients also found that INR levels greater than 2.0 can be associated with an increased risk of hemorrhage. This study demonstrated that in patients with atrial fibrillation, the risk of stroke sharply increased when the mean INR was below 2.0. It is important to understand the therapeutic purpose of anticoagulation and that subtherapeutic levels, although associated with lower incidents of bleeding, may deviate from accomplishing the ultimate purpose of anticoagulation therapy. ${ }^{23}$ Experts have suggested that warfarin is underutilized in patients secondary to the perceived bleeding risk. ${ }^{24}$ Other studies show that although increased intensity can result in a higher risk of bleeding, the incidence is not excessive. Pooled data from five randomized controlled trials demonstrated that major hemorrhage in patients on warfarin was $1.3 \%$ compared to $1.0 \%$ in both the control and aspirin groups. ${ }^{11}$ Similarly, other studies found that anticoagulation therapy is superior to aspirin-clopidogrel combinations in preventing recurrent thromboembolic events. ${ }^{12,25,26}$ Although increased intensity of anticoagulation can theoretically increase bleeding risk, the reduction of INR goals would not be recommended in most populations as the anticoagulation effects of warfarin will not be as efficacious. Instead, strategies to decrease bleeding risk include discontinuation of antiplatelet agents, such as aspirin, in patients with stable coronary artery disease. ${ }^{26}$

Numerous patient inherent characteristics that have been associated with increased bleeding risk include increasing age, presence of hypertension, diabetes, anemia, congestive heart failure, female sex, and history of stroke or transient ischemic attack. ${ }^{2,4,11,14,15,23,24,26}$ One study showed that the relative risk of intracranial hemorrhage in patients greater than 80 years of age compared to patients $70-80$ years is $2.5 .^{2}$ Conversely, increasing age is associated with a higher risk of morbidity and mortality from the underlying coagulopathic process. ${ }^{5}$ Other studies demonstrated similar findings that the morbidity and mortality from an underlying coagulopathic disorder, especially atrial fibrillation, increases with age. ${ }^{11,15}$ Therefore, age should not be used solely as a contraindication to warfarin therapy. Elderly patients should be initiated on lower doses of warfarin to attain a therapeutic level, as the common starting dose of $5 \mathrm{mg}$ may be too high. More frequent INR testing should be employed in this population. ${ }^{14}$

Patients with renal and hepatic disease, diabetes mellitus, heart failure, and hypertension have an increased risk of bleeding on warfarin therapy., ${ }^{411,14,26}$ One study found that adequate control of blood pressure in hypertensive patients was associated with a $38 \%$ decrease in major vascular events and 34\% decrease in hemorrhagic stroke. ${ }^{26}$ 
Hospitalized patients, especially those with sepsis and other such hypermetabolic states, have varied response to warfarin therapy. ${ }^{14}$ It is important to understand these risk factors and provide appropriate treatment to lessen its potential increase in bleeding risk. Those patients should also undergo more frequent INR testing to ensure that the level of anticoagulation remains therapeutic.

Risk factors that can easily be amended, if appropriately identified, include lack of patient knowledge and compliance. ${ }^{14,27,28}$ The issue of noncompliance is prevalent in both the young and elderly populations. ${ }^{14}$ One study found that younger patients may actually be slightly more noncompliant. The mean age of noncompliant patients was 54 years, compared to that of 69 years of those found to be compliant. This study indicated that lack of compliance can be a result of the lack of a primary care physician, a feeling of dissatisfaction about the medical condition, and a lack of understanding of the underlying medical condition. ${ }^{27}$ A similar pilot study examined patients' knowledge following initiation of anticoagulation therapy for atrial fibrillation. Fewer than half of all patients were able to name atrial fibrillation as their diagnosis. Approximately one-half of patients were aware of the possibility of thromboembolic events with this diagnosis, which improved to $70 \%$ following formal teaching. Only $21 \%$ of patients understood that anticoagulation therapy helps to prevent strokes, improving to only $27 \%$ with formal teaching. ${ }^{28}$ Therefore, formal education by both a cardiologist and primary care physician is important, and emphasis on the importance of warfarin therapy will help to avoid lack of compliance and medication errors. Patients are strongly encouraged to have a primary care physician to participate in management of warfarin therapy.

Variations in INR monitoring protocols exist between different medical centers. This can result in nontherapeutic levels of warfarin, further increasing the bleeding risk..$^{15,29}$ One large study of 526 INR monitoring sites and 3,371 patients found that the time in therapeutic range averaged $65 \%{ }^{29}$ Another study had a time in therapeutic range of 58\% in a cohort of 472 patients. ${ }^{15}$ Others report incidences as low as $29 \% .^{29}$ As a physician, it is important to ensure that adequate INR monitoring occurs. It is important to understand the variation in INR that can result with warfarin therapy and be aggressive in ensuring that supratherapeutic levels are not potentiating bleeding incidents.

Diet and medication changes are two other factors that can increase the risk of bleeding. ${ }^{1,14}$ Many common medications, including acetaminophen, antibiotics, antidepressants, fenofibrate, nonsteroidal anti-inflammatory drugs, and proton-pump inhibitors can alter the metabolism of warfarin. Alcohol can also affect its metabolism. There is limited data suggesting that the influenza vaccination can cause changes in the INR as well. ${ }^{1}$ Therefore, it is important to understand these medication changes and closely monitor the INR if such changes occur. To the same effect, a patient should not be discouraged to change consumption habits of green, leafy vegetables; instead, a patient should be told to keep a somewhat consistent diet.

Multiple genetic variations affect warfarin metabolism., 14,30-32 More than 30 genes have been associated with its metabolism. ${ }^{14}$ Polymorphisms of the cytochrome P450 2c9 enzyme decrease metabolism of warfarin, increasing risk of bleeding. Variations of the vitamin $\mathrm{K}$ epoxide reductase complex subunit 1 gene and the VKORC1 enzyme can alter metabolism as well. ${ }^{2,14}$ A retrospective study of 185 patients found that more than $30 \%$ had at least one variant in the cytochrome P450 2c9 allele, increasing risk for supratherapeutic INRs. ${ }^{30}$ Another study of 297 patients found that initial variability in the INR response to warfarin is more strongly associated with genetic variability, yet the ultimate influence of this variability is not of clinical significance in patients with stable INR values. ${ }^{31}$ Race and ethnicity have also been thought to affect metabolism of the drug, yet data remains somewhat limited. ${ }^{30}$ The clinical significance of these variants is controversial, as ultimately each individual patient will ultimately develop their own warfarin-dosing regimen. ${ }^{30,31}$ Testing for such genetic alterations should not routinely be performed.

\section{Risk assessment}

Different scoring systems have been developed that incorporate many of the risk factors discussed (Table 3). Each scoring system adds certain points per patient characteristic, and the total score can estimate bleeding risk. Many risk factors are similar between scoring systems, including older age, hypertension, diabetes, anemia, history of bleeding, and alcohol and drug use. ${ }^{7,24,33-35,37}$ One system incorporates the Congestive heart failure, Hypertension, Age, Diabetes mellitus, Stroke/thromboembolism $\left(\mathrm{CHADS}_{2}\right)$ scoring system that is used to assess risk of thromboembolic events in patients with atrial fibrillation. Interestingly, just as the risk of a thromboembolic event increases with $\mathrm{CHADS}_{2}$ score, so does the risk of major bleeding. ${ }^{34}$ Two of the most commonly used systems include the Hepatic or renal disease, Ethanol abuse, Malignancy, Older (age $>75$ years), Reduced platelet count or function, Hypertension (uncontrolled), Anemia, Genetic factors, Excessive fall risk, and Stroke 


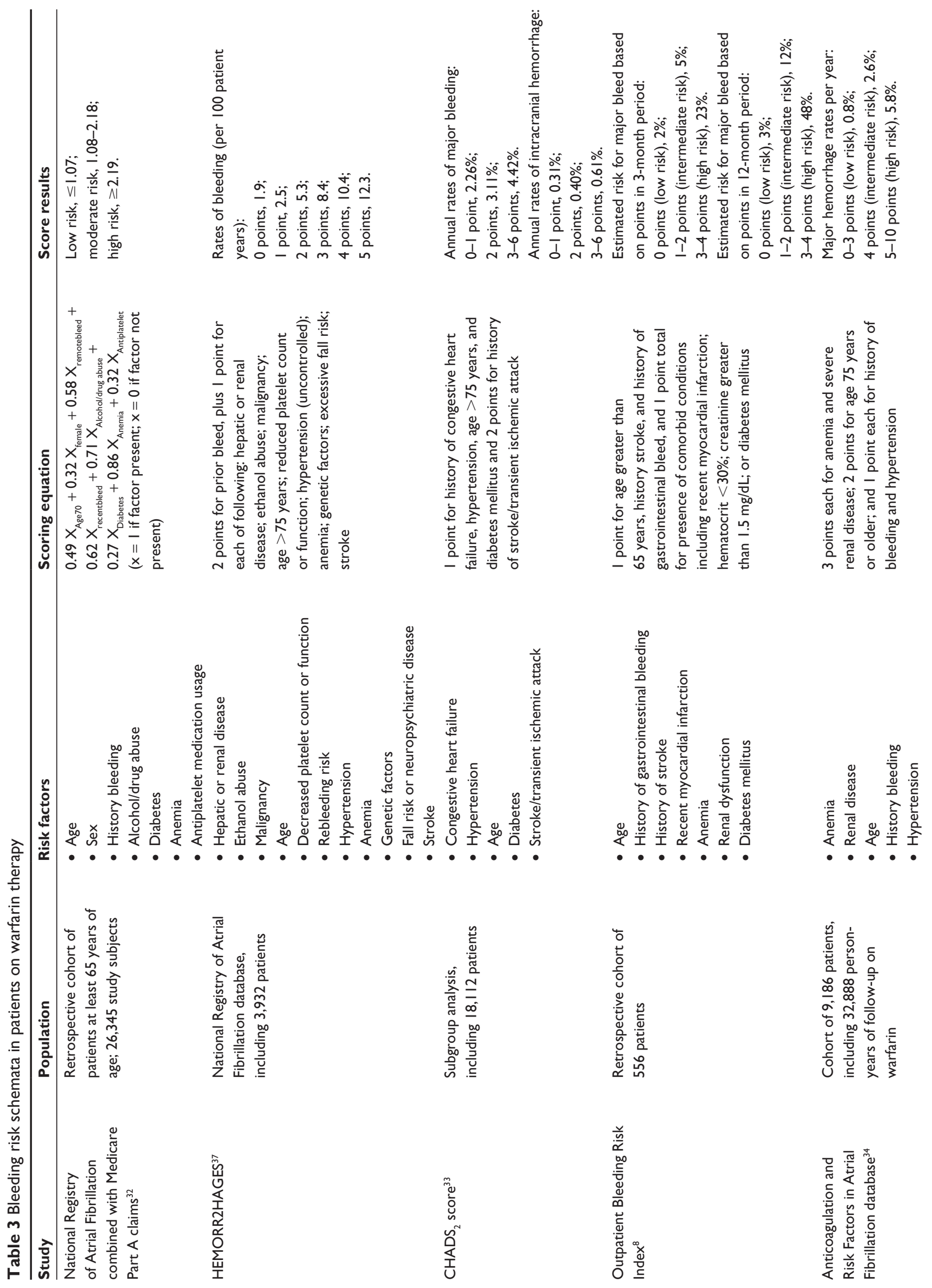




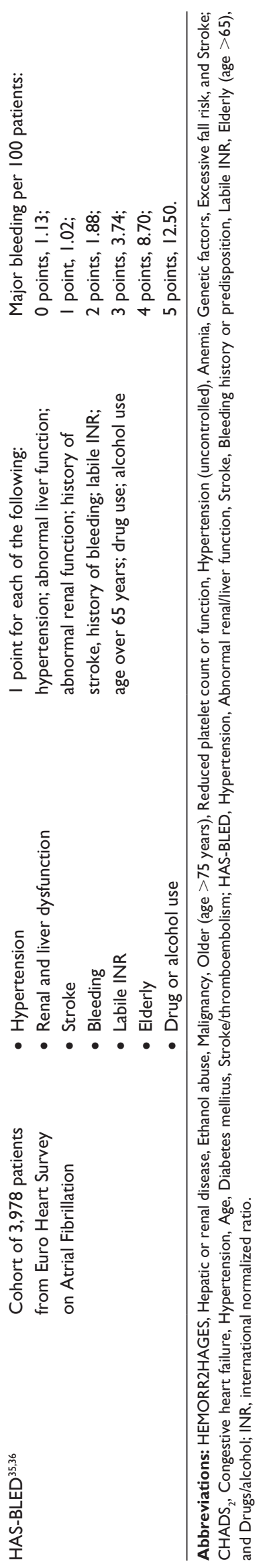

(HEMORR2HAGES) and Hypertension, Abnormal renal/ liver function, Stroke, Bleeding history or predisposition, Labile INR, Elderly (age $>65$ ), and Drugs/alcohol (HASBLED) schemata, with the HAS-BLED system thought to be the most accurate and easiest to use. ${ }^{33,37,38}$ Patients are assigned points based on the presence of such risk factors, and each point corresponds to a predicted annual risk of major bleeding that is based on the cohort used in the study. ${ }^{36}$ Similarly, the HEMORR2HAGES scoring system uses the same factors as HAS-BLED with the addition of malignancy, reduced platelet count or function, anemia, genetic factors, and excessive fall risk. ${ }^{33}$ Although these scoring systems are based on cohorts of patients with atrial fibrillation, physicians can apply them to all subsets of patients requiring warfarin anticoagulation. This can give the physician and patient a quantitative measure of bleeding risk, which can aid in the decision to initiate warfarin therapy.

Scoring systems have also been developed to assess the potential benefit of anticoagulation therapy (Table 4). For example, in patients with atrial fibrillation, the CHADS2 or Congestive heart failure, Hypertension, Age ( $>75)$, Diabetes mellitus, Stroke/TIA/Thromboembolism, Vascular disease, Age (65-74 years), Sex category ( $\left.\mathrm{CHA}_{2} \mathrm{DS}_{2} \mathrm{VAsc}\right)$ have been developed to assess stroke risk. ${ }^{39-41}$ Current guidelines recommend anticoagulation in patients with $\mathrm{CHADS}_{2}$ or $\mathrm{CHA}_{2} \mathrm{DS}_{2}$ VASc scores of greater than 1 ,

Table 4 Stroke risk scoring schemata in patients with atrial fibrillation

\begin{tabular}{lll}
\hline Schemata & Criteria & Risk \\
\hline CHADS $_{2}{ }^{38}$ & - Congestive heart failure (I point) & Annual stroke risk: \\
& - Hypertension (I point) & 0 points, I.9\%; \\
& - Age $\geq 75$ years (I point) & I point, $2.8 \% ;$ \\
& - Diabetes (I point) & 2 points, $4.0 \% ;$ \\
& - Prior stroke/transient ischemic & 3 points, $5.9 \% ;$ \\
& attack (2 points) & 4 points, $8.5 \% ;$ \\
& & 5 points, $12.5 \% ;$ \\
$\mathrm{CHA}_{2} \mathrm{DS}_{2}$ & - Congestive heart failure (I point) & Annual stroke risk: \\
$\mathrm{VASc}^{39}$ & - Hypertension (I point) & 0 points, $0 \% ;$ \\
& - Age $\geq 75$ years (2 points) & I point, $1.3 \% ;$ \\
& - Diabetes (I point) & 2 points, $2.2 \% ;$ \\
& - Prior stroke/transient ischemic & 3 points, $3.2 \% ;$ \\
& attach (2 points) & 4 points, $4.0 \% ;$ \\
& - Vascular disease (I point) & 5 points, $6.7 \% ;$ \\
& - Sge $65-74$ years (I point) & 6 points, $9.8 \% ;$ \\
& & 7 points, $9.6 \% ;$ \\
& & 8 points, $6.7 \% ;$ \\
& 9 points, $15.2 \%$. \\
\hline
\end{tabular}

Abbreviations: $\mathrm{CHADS}_{2}$, Congestive heart failure, Hypertension, Age, Diabetes mellitus, Stroke/thromboembolism; $\mathrm{CHA}_{2} \mathrm{DS}_{2} \mathrm{VASc}$, Congestive heart failure, Hypertension, Age (>75), Diabetes mellitus, Stroke/TIA/Thromboembolism, Vascular disease, Age (65-74 years), Sex category. 
while patients with scores of 0 may benefit from aspirin therapy alone. ${ }^{41-43}$ In patients with atrial fibrillation, physicians should utilize these scoring systems to help decide whether the benefits of anticoagulation outweigh the risks of bleeding.

\section{Strategies for managing bleeding risk}

Other special situations exist in which patients on warfarin therapy are at a transiently increased risk of bleeding, including during perioperative periods. ${ }^{2,44-46}$ Patients with atrial fibrillation, for instance, may need to undergo atrial ablation procedures. During these procedures, patients are given varying doses of heparin which is monitored with the activated clotting time (ACT). Variations in the ACT, along with potential remnant warfarin anticoagulation, can increase risk of bleeding. ${ }^{45,46}$ Although recent studies suggest that continued anticoagulation in patients undergoing catheter ablation and device implantation procedures may have less bleeding complications with continued anticoagulation on either warfarin or dabigatran, instead of a transient disruption in therapy, further data is needed. ${ }^{47,48}$ Patients undergoing cardiac catheterization, especially for acute cardiac syndromes, may benefit by using a radial approach. $^{2}$

Patients undergoing surgical intervention can also be at increased risk. In such cases, the American College of Chest Physicians' guidelines suggest that warfarin therapy should be generally stopped 5 days prior to the procedure and, depending on the individual patient, bridging therapy with low-molecular-weight heparin or other heparin products that can be given. Patients can usually resume warfarin therapy 12 to 24 hours following the intervention with lower-molecular-weight bridging therapy until the INR is therapeutic..$^{46,49-51}$ If the bleeding risk of the procedure is felt to be high, including procedures such as craniotomies, spinal surgery, or partial organ removals, consideration should be given to holding anticoagulation until the risk subsides. Generally, those patients with venous thromboembolism that developed within a 3-month period and arterial thrombosis within a 1-month period would require bridging therapy. Patients should be stratified, based on risk. ${ }^{50}$ Atrial fibrillation patients at high risk for thromboembolism with a CHADS2 score of 5 or above should be considered for bridging therapy as well. In those with scores of 3 or 4 , consideration should be given to the individual patient and surgical procedure. Patients with mechanical valves, except for those in the aortic region, would need bridging, while those with bioprosthetic valves would not, unless associated with atrial fibrillation. ${ }^{49,50}$ It is important to proactively plan for such procedures and educate patients on discontinuation of warfarin therapy, if needed.

One other important consideration is the use of warfarin therapy in conjunction with dual antiplatelet therapy, such as aspirin and clopidogrel. Indications for concomitant antiplatelet use includes primary prevention of coronary artery disease, secondary prevention after a diagnosis of coronary artery disease, maintenance therapy following percutaneous coronary interventions, or stroke. ${ }^{51}$ Current American College of Cardiology/American Heart Association guidelines suggest reducing the INR goal in this cohort to 2.0-2.5, especially in elderly patients. Strict INR monitoring is highly encouraged, and patients should be educated on the increased bleeding risk. ${ }^{52-54}$ One study that evaluated the risk of traumatic intracranial hemorrhage in patients with mild head trauma suggested that patients on either warfarin or clopidogrel may have increased risk of intracranial hemorrhage, even in absence of clinical signs or symptoms, adding to the increased bleeding risk in patients on combination treatment. ${ }^{55}$

\section{Newer anticoagulants}

Anticoagulation continues to be an evolving field. Although warfarin is the mainstay therapy, many other newer anticoagulants have been developed with intent to decrease risk of bleeding. Three trials comparing novel anticoagulants to warfarin include the RE-LY (Randomized Evaluation of Long-Term Anticoagulation Therapy), ROCKET-AF, and ARISTOTLE trials, comparing dabigatran, rivaroxaban, and apixaban, respectively. 5,9,56,57 The RE-LY trial showed that dabigatran was noninferior to warfarin and that the $110 \mathrm{mg}$ dosing was associated with fewer bleeding events. ${ }^{10}$ The ROCKET-AF trial showed no significant difference in bleeding incidents, yet there were fewer fatal and intracranial bleeds in patients on rivaroxaban..$^{5}$ Apixaban was found to be superior to warfarin in decreasing bleeding risk in the ARISTOTLE trial. ${ }^{56,57}$ Dabigatran, rivaroxaban, and apixaban are all currently approved for prevention of thromboembolic events in atrial fibrillation, while rivaroxaban is the only medication with an additional indication for venous thrombosis and pulmonary embolism. ${ }^{57}$ Most of the data on the newer anticoagulants come from cohorts of patients with atrial fibrillation with few comorbidities, yet one of the key components to the success of future anticoagulants is the ability to decrease bleeding risk, further emphasizing this concern. 
Although these newer anticoagulants have been introduced, warfarin will continue to be used and likely the mainstay therapy. Antidotes have not been developed in cases of bleeding, and the cost of the newer drugs can be significantly higher than the cost of warfarin. Studies have evaluated a cost benefit analysis using dabigatran based on results from the RE-LY trial. Dabigatran was shown to be more cost-effective in populations at high risk of hemorrhage or high risk of stroke unless INR control was excellent. Otherwise, warfarin was more cost-effective in moderate-risk populations. ${ }^{58}$ Similar studies report that the other novel anticoagulants are cost-effective alternates to warfarin, depending on medication pricing and patient predisposition to neurological events. ${ }^{59}$ Studies assessing the newer anticoagulants have not included patients with renal or hepatic dysfunction. As well, indications of newer anticoagulants are not as diverse as are those for warfarin, including prevention of thromboembolic disease in atrial fibrillation, venous thromboembolism, pulmonary embolism, and prosthetic valves. ${ }^{5,56,57}$

\section{Conclusion}

Warfarin therapy is an important medication in the prevention of thrombosis and thromboembolism. Although it is very efficacious, warfarin carries the risk of bleeding. It is important to understand which factors can attribute to this bleeding risk and make an effort to lessen its effects. Each patient should be assessed individually prior to starting warfarin therapy, and therapy should be personalized to that particular patient, with emphasis on monitoring and patient education. Although a bleeding risk will always remain, careful monitoring of the patients can dramatically reduce this risk.

\section{Disclosure}

The authors report no conflicts of interest in this work.

\section{References}

1. Holbrook AM, Pereira JA, Labiris R, et al. Systematic overview of warfarin and its drug and food interactions. Arch Intern Med. 2005;165(10):1095-1106.

2. Lip GY, Andreotti F, Fauchier L, et al. Bleeding risk assessment and management in atrial fibrillation patients. Executive summary of a position document from the European Heart Rhythm Association [EHRA], endorsed by the European Society of Cardiology [ESC] Working Group on Thrombosis. Thromb Haemost. 2011;106(6):997-1011.

3. Garcia DA, Lopes RD, Hylek EM. New-onset atrial fibrillation and warfarin initiation: high risk periods and implications for new antithrombotic drugs. Thromb Haemost. 2010;104(6):1099-1105.

4. DiMarco JP, Flaker G, Waldo AL, et al. Factors affecting bleeding risk during anticoagulant therapy in patients with atrial fibrillation: observations from the Atrial Fibrillation Follow-up Investigation of Rhythm Management (AFFIRM) Study. Am Heart J. 2005;149(4):650-656.
5. Patel MR, Mahaffey KW, Garg J, et al. Rivaroxaban versus warfarin in nonvalvular atrial fibrillation. N Engl J Med. 2011;365(10):883-891.

6. Go AS, Hylek EM, Chang Y, et al. Anticoagulation therapy for stroke prevention in atrial fibrillation: how well do randomized trials translate into clinical practice? JAMA. 2003;290(20):2685-2692.

7. Beyth RJ, Quinn LM, Landefeld CS. Prospective evaluation of an index for predicting the risk of major bleeding in outpatients treated with warfarin. Am J Med. 1998;105(2):91-99.

8. Wells PS, Forgie MA, Simms M, et al. The outpatient bleeding risk index: validation of a tool for predicting bleeding rates in patients treated for deep venous thrombosis and pulmonary embolism. Arch Intern Med. 2003;163(8):917-920.

9. Kuijer PM, Hutten BA, Prins MH, Büller HR. Prediction of the risk of bleeding during anticoagulant treatment for venous thromboembolism. Arch Intern Med. 1999;159(5):457-460.

10. Connolly SJ, Ezekowitz MD, Yusuf S, et al. Dabigatran versus warfarin in patients with atrial fibrillation. $N$ Engl J Med. 2009;361(12): 1139-1151.

11. Risk factors for stroke and efficacy of antithrombotic therapy in atrial fibrillation. Analysis of pooled data from five randomized controlled trials. Arch Intern Med. 1994;154(13):1449-1457.

12. ACTIVE Writing Group of the ACTIVE Investigators; Connolly S, Pogue J, et al. Clopidogrel plus aspirin versus oral anticoagulation for atrial fibrillation in the Atrial fibrillation Clopidogrel Trial with Irbesartan for prevention of Vascular Events (ACTIVE W): a randomised controlled trial. Lancet. 2006;367(9526):1903-1912.

13. Albers GW, Diener HC, Frison L, et al. Ximelagatran vs warfarin for stroke prevention in patients with nonvalvular atrial fibrillation: a randomized trial. JAMA. 2005;293(6):690-698.

14. Palareti G, Cosmi B. Bleeding with anticoagulation therapy - who is at risk, and how to best identify such patients. Thromb Haemost. 2009;102(2):268-278.

15. Hylek EM, Evans-Molina C, Shea C, Henault LE, Regan S. Major hemorrhage and tolerability of warfarin in the first year of therapy among elderly patients with atrial fibrillation. Circulation. 2007; 115(21):2689-2696.

16. Douketis JD, Foster GA, Crowther MA, Prins MH, Ginsberg JS. Clinical risk factors and timing of recurrent venous thromboembolism during the initial 3 months of anticoagulant therapy. Arch Intern Med. 2000;160(22):3431-3436.

17. Landefeld CS, Goldman L. Major bleeding in outpatients treated with warfarin: incidence and prediction by factors known at the start of outpatient therapy. Am J Med. 1989;87(2):144-152.

18. Linkins LA, Choi PT, Douketis JD. Clinical impact of bleeding in patients taking oral anticoagulant therapy for venous thromboembolism: a meta-analysis. Ann Intern Med. 2003;139(11):893-900.

19. Lehto M, Snapinn S, Dickstein K, Swedberg K, Nieminen MS; OPTIMAAL investigators. Prognostic risk of atrial fibrillation in acute myocardial infarction complicated by left ventricular dysfunction: the OPTIMAAL experience. Eur Heart J. 2005;26(4):350-356.

20. Gomes T, Mamdani MM, Holbrook AM, Paterson JM, Hellings C, Juurlink DN. Rates of hemorrhage during warfarin therapy for atrial fibrillation. CMAJ. 2013;185(2):E121-E127.

21. Rosand J, Eckman MH, Knudsen KA, Singer DE, Greenberg SM. The effect of warfarin and intensity of anticoagulation on outcome of intracerebral hemorrhage. Arch Intern Med. 2004;164(8):880-884.

22. Naganuma M, Shiga T, Sato K, et al. Clinical outcome in Japanese elderly patients with non-valvular atrial fibrillation taking warfarin: a single-center observation study. Thromb Res. 2012;130(1): 21-26.

23. Fang MC, Chang Y, Hylek EM, et al. Advanced age, anticoagulation intensity, and risk for intracranial hemorrhage among patients taking warfarin for atrial fibrillation. Ann Int Med. 2004;141(10): $745-752$.

24. Shireman TI, Mahnken JD, Howard PA, Kresowik TF, Hou Q, Ellerbeck EF. Development of a contemporary bleeding risk model for elderly warfarin recipients. Chest. 2006;13(5):1390-1396. 
25. Kearon C, Ginsberg JS, Kovacs MJ, et al; Extended Low-Intensity Anticoagulation for Thrombo-Embolism Investigators. Comparison of low-intensity warfarin therapy with conventional-intensity warfarin therapy for long-term prevention of recurrent venous thromboembolism. N Engl J Med. 2003;349(7):631-639.

26. Arima H, Hart RG, Colman S, et al. Perindopril-based blood pressure-lowering reduces major vascular events in patients with atrial fibrillation and prior stroke or transient ischemic attack. Stroke. 2005;36(10):2164-2169.

27. Arnsten JH, Gelfand JM, Singer DE. Determinants of compliance with anticoagulation: A case-control study. Am J Med. 1997;103(1):11-17.

28. Lane DA, Ponsford J, Shelley A, Sirpal A, Lip GY. Patient knowledge and perceptions of atrial fibrillation and anticoagulant therapy: effects of an educational intervention programme. The West Birmingham Atrial Fibrillation Project. Int J Cardiol. 2006;110(3):354-358.

29. Connolly SJ, Pogue J, Eikelboom J, et al; ACTIVE W Investigators. Benefit of oral anticoagulant over antiplatelet therapy in atrial fibrillation depends on the quality of international normalized ratio control achieved by centers and countries as measured by time in therapeutic range. Circulation. 2008;118(20):2029-2037.

30. El Rouby S, Mestres CA, LaDuca FM, Zucker ML. Racial and ethnic differences in warfarin response. J Heart Valve Dis. 2004;13(1):15-21.

31. Schwarz UI, Ritchie MD, Bradford Y, et al. Genetic determinants of response to warfarin during initial anticoagulation. $N$ Engl J Med. 2008;358(10):999-1008.

32. Higashi MK, Veenstra DL, Kondo LM, et al. Association between CYP2C9 genetic variants and anticoagulation-related outcomes during warfarin therapy. JAMA. 2002;287(13):1690-1698.

33. Gage BF, Yan Y, Milligan PE, et al. Clinical classification schemes for predicting hemorrhage: results from the National Registry of Atrial Fibrillation (NRAF). Am Heart J. 2006;151(3):713-719.

34. Oldgren J, Alings M, Darius H, et al. Risks for stroke, bleeding, and death in patients with atrial fibrillation receiving dabigatran or warfarin in relation to the CHADS2 score: a subgroup analysis of the RE-LY Trial. Ann Intern Med. 2011;155(10):660-667.

35. Fang MC, Go AS, Chang Y, et al. A new risk scheme to predict warfarin-associated hemorrhage: The ATRIA (Anticoagulation and Risk Factors in Atrial Fibrillation) Study. J Am Coll Cardiol. 2011;58(4): 395-401.

36. Lip GY, Frison L, Halperin JL, Lane DA. Comparative validation of a novel risk score for predicting bleeding risk in anticoagulated patients with atrial fibrillation: the HAS-BLED (Hypertension, Abnormal Renal/ Liver Function, Stroke, Bleeding History or Predisposition, Labile INR, Elderly, Drugs/Alcohol Concomitantly) Score. J Am Coll Cardiol. 2011;57(2):173-180.

37. Pisters R, Lane DA, Nieuwlaat R, de Vos CB, Crijns HJ, Lip GY. A novel user-friendly score (HAS-BLED) to assess 1-year risk of major bleeding in patients with atrial fibrillation: the Euro Heart Survey. Chest. 2010;138(5):1093-1100.

38. Apostolakis S, Lane DA, Guo Y, Buller H, Lip GY. Performance of the HEMORR(2)HAGES, ATRIA, and HAS-BLED bleeding riskprediction scores in patients with atrial fibrillation undergoing anticoagulation: the AMADEUS (evaluating the use of SR34006 compared to warfarin or acenocoumarol in patients with atrial fibrillation) study. J Am Coll Cardiol. 2012;60(9):861-867.

39. Gage BF, Waterman AD, Shannon W, Boechler M, Rich MW, Radford MJ. Validation of clinical classification schemes for predicting stroke: results from the National Registry of Atrial Fibrillation. JAMA. 2001;285(22):2864-2870.

40. Olesen JB, Lip GY, Hansen ML, et al. Validation of risk stratification schemes for predicting stroke and thromboembolism in patients with atrial fibrillation: nationwide cohort study. BMJ. 2011;342:d124.

41. Camm AJ, Kirchhof P, Lip GY, et al; European Heart Rhythm Association; European Association for Cardio-Thoracic Surgery; ESC Committee for Practice Guidelines. Guidelines for the management of atrial fibrillation: the Task Force for the Management of Atrial Fibrillation of the European Society of Cardiology (ESC). Europace. 2010;12(10):1360-1420.
42. European Heart Rhythm Association; Heart Rhythm Society, Fuster V, Rydén LE, Cannom DS, et al; American College of Cardiology; American Heart Association Task Force on Practice Guidelines; European Society of Cardiology Committee for Practice Guidelines; Writing Committee to Revise the 2001 Guidelines for the Management of Patients With Atrial Fibrillation. ACC/AHA/ESC 2006 guidelines for the management of patients with atrial fibrillation - executive summary: a report of the American College of Cardiology/American Heart Association Task Force on Practice Guidelines and the European Society of Cardiology Committee for Practice Guidelines (Writing Committee to Revise the 2001 Guidelines for the Management of Patients With Atrial Fibrillation). J Am Coll Cardiol. August 15, 2006;48(4):854-906.

43. You JJ, Singer DE, Howard PA, et al; American College of Chest Physicians. Antithrombotic Therapy for Atrial Fibrillation: Antithrombotic Therapy and Prevention of Thrombosis. 9th ed. American College of Chest Physicians Evidence-Based Clinical Practice Guidelines. Chest. 2012;141(Supp1 2):e531S-e575S.

44. Snipelisky D, Kauffman C, Prussak K, Johns G, Venkatachalam K, Kusumoto F. A comparison of bleeding complications post-ablation between warfarin and dabigatran. J Interv Card Electrophysiol. 2012;35(1):29-33.

45. Zak J. Ablation to treat atrial fibrillation: beyond rhythm control. Crit Care Nurse. 2010;30(6):68-79.

46. BRIDGE Study Investigators. Bridging anticoagulation: is it needed when warfarin is interrupted around the time of a surgery or procedure? Circulation. 2012;125(12):e496-e498.

47. Di Biase L, Burkhardt JD, Santangeli P, et al. Periprocedural stroke and bleeding complications in patients undergoing catheter ablation of atrial fibrillation with different anticoagulation management: Results from the "COMPARE" randomized trial. Heart Rhythm Society. 2013;(Suppl LBCT-01):LB01-01. Available from http://www.google. com/url?q=http://www.hrsonline.org/content/download/14043/630229/ file/Late-Breaking\%2520Clinical\%2520Trials\%2520Session $\% 25201$. pdf\&sa $=$ U\&ei $=$ CKbsUdjRK7KEygHO-YC4Bg\&ved $=0 \mathrm{CB} 8 \mathrm{QFjAC}$ \&usg=AFQjCNHLgU6ulLBXo6YD2jMooLXpv-1bXA. Accessed July 24, 2013

48. Birnie DH, Healey JS, Wells GA, et al; BRUISE CONTROL Investigators. Pacemaker or defibrillator surgery without interruption of anticoagulation. N Engl J Med. 2013;368(22):2084-2093.

49. Harrison RW, Ortel TL, Becker RC. To bridge or not to bridge: these are the questions. J Thromb Thrombolysis. 2012;34(1):31-35.

50. Douketis JD, Spyropoulos AC, Spencer FA, et al. Perioperative Management of Antithrombotic Therapy: Antithrombotic Therapy and Prevention of Thrombosis. 9th ed. American College of Chest Physicians Evidence-Based Clinical Practice Guidelines. Chest. 2012; 141(2 Suppl):e326S-e350S.

51. Dans AL, Connolly SJ, Wallentin L, et al. Concomitant use of antiplatelet therapy with dabigatran or warfarin in the Randomized Evaluation of Long-Term Anticoagulation therapy (RE-LY) Trial. Circulation. 2013;127(5):634-640.

52. Antman EM, Hand M, Armstrong PW, et al; 2004 Writing Committee Members. 2007 focused update of the ACC/AHA 2004 Guidelines for the Management of Patients With ST-Elevation Myocardial Infarction: a report of the American College of Cardiology/American Heart Association Task Force on Practice Guidelines: developed in collaboration with the Canadian Cardiovascular Society endorsed by the American Academy of Family Physicians: 2007 Writing Group to review new evidence and update the ACC/AHA 2004 Guidelines for the Management of Patients With ST-Elevation Myocardial Infarction, writing on behalf of the 2004 Writing Committee. Circulation. 2008;117(2):296-329.

53. King SB 3rd, Smith SC Jr, Hirshfeld JW Jr, et al; 2005 Writing Committee Members. 2007 Focused update of the ACC/AHA/SCAI 2005 Guideline Update for Percutaneous Coronary Intervention: a report of the American College of Cardiology/American Heart Association Task Force on Practice Guidelines: 2007 Writing Group to review new evidence and update the 2005 ACC/AHA/SCAI Guideline Update for Percutaneous Coronary Intervention, writing on behalf of the 2005 Writing Committee. Circulation. 2008;117: 261-295. 
54. Fuster V, Ryden LE, Cannom DS, et al. ACC/AHA/ESC 2006 guidelines for the management of patients with atrial fibrillation: a report of the American College of Cardiology/American Heart Association Task Force on Practice Guidelines and the European Society of Cardiology Committee for Practice Guidelines (Writing Committee to Review the 2001 Guidelines for the Management of Patients with Atrial Fibrillation). Circulation. 2006;114:e257-e354.

55. Nishijima DK, Offerman SR, Ballard DW, et al. Risk of traumatic intracranial hemorrhage in patients with head injury and preinjury warfarin or clopidogrel use. Acad Emerg Med. 2013;20(2):140-145.

56. Granger CB, Alexander JH, McMurray JJ, et al; ARISTOTLE Committees and Investigators. Apixaban versus warfarin in patients with atrial fibrillation. $N$ Engl J Med. 2011;365(11):981-992.
57. EINSTEIN-PE Investigators; Büller HR, Prins MH, Lensin AW, et al. Oral rivaroxaban for the treatment of symptomatic pulmonary embolism. N Engl J Med. 2012;366(14):1287-1297.

58. Shah SV, Gage BF. Cost-effective of dabigatran for stroke propylaxis in atrial fibrillation. Circulation. 2011;123(22):2562-2570.

59. Harrington AR, Armstrong EP, Nolan PE Jr, Malone DC. Cost-effectiveness of apixaban, dabigatran, rivaroxaban, and warfarin for stroke prevention in atrial fibrillation. Stroke. 2013;44(6):1676-1681.
Journal of Blood Medicine

\section{Publish your work in this journal}

The Journal of Blood Medicine is an international, peer-reviewed, open access, online journal publishing laboratory, experimental and clinical aspects of all topics pertaining to blood based medicine including but not limited to: Transfusion Medicine; Blood collection, Donor issues, Transmittable diseases, and Blood banking logistics; Immunohematology; Artificial and alternative

\section{Dovepress}

blood based therapeutics; Hematology; Biotechnology/nanotechnology of blood related medicine; Legal aspects of blood medicine; Historical perspectives. The manuscript management system is completely online and includes a very quick and fair peer-review system. Visit http://www.dovepress.com/ testimonials.php to read real quotes from published authors.

Submit your manuscript here: http://www.dovepress.com/Journal-of-blood-medicine-journal 